\title{
SPIDIA
}

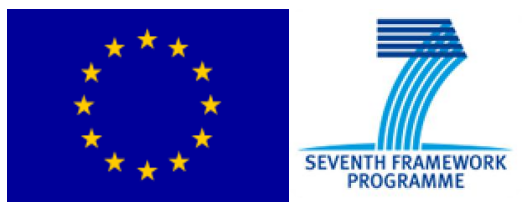

\author{
SCHEME OF PROCEDURE: \\ SPIDIA-RNA \\ pre-analytical survey \\ Protocol B - EDTA tubes(RT) \\ $2^{\text {nd }}$ ring trial
}

Dear participant,

SPIDIA (www.spidia.eu) thanks you to join us to this pre-analytical external quality assessment survey for RNA. SPIDIA will contribute to the standardisation and improvement of procedures and tools for pre-analytical intervention. The individual steps, such as sample handling, stabilisation and storage, will be standardised and integrated in one holistic process combining classical and molecular diagnostics. SPIDIA aims at developing and validating the necessary guidelines and tools that will make possible the production of new knowledge and its transation into practical applications in the area of health and medicine.

The aim of SPIDIA-RNA is to evaluate the stability and integrity on RNA from blood sample, in particular focusing the analysis in relation of :

- $\quad$ the method of sample collection,

- the time interval between collection and extraction,

- the procedure of extraction,

- $\quad$ the storage and shipping of extracted sample.

In thiscall, SPIDIA asksyou to perform RNA extraction from two blood samplescollected in EDTA tubes sent by SPIDIA.

Please, find here enclosed all the details necessary to perform this SPIDIA-RNA survey.

Good luck and our best regards,

Uwe Oelmueller

Coordinator of the SPIDIA Project

Mario Pazzagli

Leader of the WP 12: Evidence-based Quality Guidelines for the pre-analytical phase of Blood Samples 
TO BE PERFORMED IMMEDIATELY UPON ARRIVAL:

- DO NOT DISCARD THE SPIDIA BOX SINCE IT IS NECESSARY FOR THE SHIPMENT OF YOUR SAMPLES.

- CHECK THE AVAILABILITY OF DRY ICE (3 kg) IN YOUR LABORATORY SINCE IT WILL BE NECESSARY TO PERFORM THE SHIPMENT OF YOUR SAMPLES TO SPIDIA UNFI LABORATORY.

\section{SUMMARY OF THE SCHEME:}

- Why have I received two samples?

- What does the shipping box contain?

- What do you do with the samples?

- How do you send your results to SPIDIA?

- How do you send your samplesto SPIDIA?

\section{Why have I received two samples?}

You receive two blood samples in EST tubes Tube C XXX and Tube D XXX (XXX is our internal number referring to your lab).

Please, extract both of them by using your proceduresand following this protocol.

You will receive the report of your performance only about RNA extracted from Tube C;

Tube $D$ will be used for evidence based guidelines, you will be not judged on this result.

\section{What does the shipping box contain?}

In this box you find the samples, the protocol and the Result Form to record your data.

- 1 vial labelled Tube C XXX contains $3 \mathrm{ml}$ of whole blood in a EST tube. Blood was collected using EDTA asanticoagulant.

- 1vial labelled Tube D XXX contains $3 \mathrm{ml}$ of whole blood in a EST tube. Blood was collected using EDTA asanticoagulant.

- 2 empty vials labelled CXXX and DXXX to send back the extracted RNAs(RNA C and RNA $D$, respectively) to SPIDIA UNIFI laboratory.

- lempty vial labelled EBXXX to send back the buffer used for RNAs elution/suspension.

- 1label with SPIDIA UNIFI laboratory address

SPIDIA UNIFI laboratory:

Prof. Mario Pazzagli

Dept. Clinical Physiopathology

O.U. Clinical Biochemistry

Viale G. Pieraccini, 6

50139 FLORENCE-ITALY

* please do not discard the shipping box (polystyrene box). You will use it to send back your RNA samples with DRY ICE (on your charge) to the SPIDIA UNIFI laboratory. 
What do you do with the samples?

Before starting the extraction, please read the result form and record all necessary information.

Blood Sample

Please, remind to invert the tubes several times before the extraction, then spin down briefly (1-3 seconds) just to remove blood from the cap, be careful not to spin down the blood cells, since this will reduce the RNA yield.

- Take Tube D XXX and put it at Room Temperature (RT)for 24h hours (it must be extracted $24 \mathrm{~h}$ after tube C).

- Take Tube C XXX and equilibrate it to room temperature before to extract RNA. Perform extraction of RNA immediately (see Note 1) following your own procedures.

- After RNA extraction from Tube C XXX, transfer the eluate to the vial labelled CXXX (RNA C), immediately perform the spectrophotometric measurements (see Note 2) on the extracted RNA (see Spectrophotometric evaluation procedure).

- Store CXXX at $-20^{\circ} \mathrm{C}$ or $-80^{\circ} \mathrm{C}$ until the shipping to SPIDIA UNIFI laboratory.

- 24h after Tube C RNA extraction, take Tube D XXX and extract corresponding RNA, following your own procedures.

- After RNA extraction from Tube D XXX, transfer the eluate to the vial labelled DXXX (RNA D), immediately (see Note 3) perform the spectrophotometric measurements on the extracted RNA (see Spectrophotometric evaluation procedure).

- Store DXXX at $-20^{\circ} \mathrm{C}$ or $-80^{\circ} \mathrm{C}$ until the shipping to SPIDIA UNIFI laboratory.

-Transfer $30 \mu \mathrm{l}$ of RNA elution/resuspension buffer in the EBXXX labelled vial and store it at room temperature. Please use the same buffer to elute/resuspend RNA C and RNA D.

Note 1 In order to minimize the impact of shipping and storage on the results, it is essential to extract Tube $\mathrm{C}$ immediately after arrival. If it is not possible to extract immediately the RNA from blood, store Tube $\mathrm{C}$ at $4^{\circ} \mathrm{C}$, and extract RNA as soon as possible. If Tube $\mathrm{C}$ is not extracted immediately, it has to be stored at $4^{\circ} \mathrm{C}$ until extraction and store also Tube $\mathrm{D}$ at $4^{\circ} \mathrm{C}$ until you start the extraction from Tube C. Put Tube D at room temperature when you start extraction of Tube $\mathrm{C}$ and incubate Tube $\mathrm{D}$ for $24 \mathrm{~h}$ at room temperature, as described above (remember that, in any case, Tube D MUST be extracted $24 \mathrm{~h}$ after Tube C, after a $24 \mathrm{~h}$ incubation at RT).

Note 2. If it is not possible to perform spectrophotometric measurements immediately after extraction on RNA C, we suggest to store RNA C at $-20^{\circ} \mathrm{C}$ or $-80^{\circ} \mathrm{C}$ in the meantime.

Note 3. If it is not possible to perform spectrophotometric measurements immediately after extraction on RNA D, we suggest to store RNA $D$ at $-20^{\circ} \mathrm{C}$ or $-80^{\circ} \mathrm{C}$ in the meantime.

\section{Spectrop hotometric evaluation procedure}

By spectrophotometric measurements you evaluate RNA concentration $(\mathrm{ng} / \mu \mathrm{l} ; \mathrm{C}=260 \mathrm{~nm} \times 40 \mathrm{x}$ dilution factor or $C=(260 \mathrm{~nm}-320 \mathrm{~nm}) \times 40 \times$ dilution factor) and purity $(\mathrm{R}=260 \mathrm{~nm} / 280 \mathrm{~nm}$ or $\mathrm{R}=260 \mathrm{~nm}-320 \mathrm{~nm}) /(280 \mathrm{~nm}-320 \mathrm{~nm})$ ) in the two extracted RNAs (CXXX and DXXX) from blood samples. Record all the data (Absorbance at $320 \mathrm{~nm}, 260 \mathrm{~nm}, 280 \mathrm{~nm}$, buffer used for dilution, dilution factor) in the Result Form.

During the spectrophotometric measurements calibrate correctly your UV blank: 
- if you measure a diluted sample: use the same solution (water or buffer) that has been used for RNA dilution;

-if you measure an entire sample: use the same solution (water or buffer) that has been used for RNA elution/resuspension

Specify in the Result form which type of blank you used.

\section{How do you send your results to SIDIA?}

Data collection: Result Form

To minimise any error in the data collection we provide you a double procedure: Result Form has to be completed by using both the paper copy and the on-line version. We encourage to store a copy of your Result Form for any further requirement.

Please, complete both the on-line and the paper version of the Result Form Before the shipment, enclose a copy of the paper version in the shipment box together with the extracted RNAs.

To enter in the personalised area of the SPIDIA website:

1 connect to the SPIDIA web site http://www.efcclm.eu/spidia/index.htm

2. select "Participant" from the "login area" section

3. upload your page using your login and password and record your data If you do not have anymore the login data, please send a request to spidiaunifi@nifi.it Data collection: Questionnaire In the personalised area of SPIDIA website, fill the Questionnaire form. Please enclose a copy of the completed Questionnaire also in the shipment of the SPIDIA box. At your request, to spidiaunifi@unifi.it, isalso possible to receive, fill and send thisform by e-mail.

\section{How do you send your samples to SPIDIA?}

Provide by yourself the dry ice. The dry ice is NOT provided by SPIDIA. The amount of dry ice must be about $3 \mathrm{~kg}$ to ensure the correct temperature during the shipping.

- Prepare the shipping box using the polystyrene box (the same in which you received the blood).

- $\quad$ Add the dry ice.

- Put the following material in the shipping box:
- RNA C : CXXX
- RNA D : DXXX
- Elution/resuspension buffer: EBXXX
- Filled Result Form
- Filled the Questionnaire

Apply the enclosed label with SPIDIA UNIFI laboratory address to the shipping box.

Send it to SPIDIA UNIFI laboratory by phone calling DHL and selecting the correct code to perform the shipment:

o if your lab is extra-ITALY the code is: 951459463

o if your lab is in ITALY the code is. 105615282

The airway bill have to be requested to your local DHL.

Fill the DHL airway bill exactly asreported in the enclosed copy.

Shipment will be free of charge.

For any question you can contact us at: spidiaunifi@unifi.it 